JURNAL RESPIRASI

JR

Vol. 2 No. 1 Januari 2016

\title{
Seorang Perempuan Terinfeksi Tuberkulosis dengan Manifestasi Sindroma Distres Napas Akut (ARDS)
}

Putu Dyah Widyaningsih, Winariani Koesoemoprodjo

Departemen Pulmonologi dan Ilmu Kedokteran Respirasi, Fakultas Kedokteran Universitas Airlangga/RSUD Dr. Soetomo

\begin{abstract}
Tuberculosis remains a global issue throughout the world. Indonesia currently ranks 4 th worldwide. Although rarely reported, TB could be one of the etiologies of Acute Respiratory Distress Syndrome. A 27-year-old woman was admitted with shortness of breath 12 days post partum with cough, loss of appetite and malaise. Chest examination revealed increased fremitus on both lungs and rhonchi on 2/3 lower part of the lung. There was edema on both of the leg. Radiologic finding suggested reticulogranuler pattern on both lungs. Laboratory showed granulocytosis, anemia and hypoalbumin with severe hypoxemia and PaO2/FIO2 ratio of 107. Transthoracic Echocardiography showed PCWP of 12,25 mmHg. Patient was diagnosed with moderate Acute Respiratory Distress Syndrome but there was no improvement after definitive antibiotic therapy. Based on clinical judgment, patients suspected of having tuberculosis and given anti tuberculosis drugs with a regimen of rifampicin, isoniazid, ethambutol, pyrazinamide, and streptomycin along with methylprednisolone and supportive therapy. Microscopic examination of acid-fast bacilli sputum shows positive result one day after the treatment started. Patient was showing significant improvement and declare cured after completed 6 month of therapy.

Conclusions: Although the incidence is rare, tuberculosis can act as the primary cause of ARDS. Early diagnosis of tuberculosis is the key point of this case. Initial therapy along with good supportive therapy should be given to ARDS patient while the underlying cause is treated.
\end{abstract}

Key words: ARDS, tuberculosis, infection, pregnancy

Correspondence: Putu Dyah Widyaningsih, Departemen Pulmonologi dan Ilmu Kedokteran Respirasi, Fakultas Kedokteran, Universitas Airlangga/RSUD Dr. Soetomo. Jl. Mayjen. Prof Dr. Moestopo 6-8 Surabaya 60286. E-mail:

\section{PENDAHULUAN}

Tuberkulosis (TB) masih merupakan masalah kesehatan dunia dan penyebab terbesar kecacatan dan kematian terutama di negara berkembang. Menurut data WHO terdapat 9,27 juta kasus baru di seluruh dunia pada tahun 2007. Sementara data tahun 2012 memperlihatkan insidens kasus TB di Indonesia menempati peringkat ke 4 setelah India, Cina, Afrika Selatan dengan rerata 0,4 juta hingga 0,5 juta kasus pertahunnya. Eradikasi dari infeksi ini tergantung dari berbagai faktor termasuk kondisi sosioekonomi, demografi dan kerentanan host serta virulensi dari agen infeksi. ${ }^{1}$ Pada beberapa kepustakaan dikatakan terdapat strain tuberkulosis dengan virulensi yang lebih tinggi dibandingkan yang lain. Penegakan diagnosis TB memperhatikan adanya gejala klinis, gambaran radiologis yang mendukung dan terutama ditemukannya basil tahan asam pada spesimen yang berasal dari sputum. ${ }^{2}$

Sayangnya diagnosis banding infeksi TB sangat bervariasi mulai dari infeksi bakteri hingga menyerupai gambaran keganasan. Acute Respiratory Distress Syndrome (ARDS) merupakan kondisi mengancam jiwa yang disebabkan oleh berbagai faktor termasuk infeksi dan trauma pada paru. Angka mortalitas mencapai $90 \%$ apabila penderita tidak ditangani secara adekuat. ${ }^{3}$ TB saat ini mulai dikenal sebagai salah satu penyebab ARDS. Walaupun persentase kasus ARDS karena TB belum diketahui secara pasti. ${ }^{4}$

Mengingat tingginya prevalensi dan insidens penyakit ini, maka diperlukan kewaspadaan untuk mencari kemungkinan adanya infeksi TB pada penderita dengan ARDS. Dari laporan serial kasus terhadap 109 penderita 
dengan TB hanya ditemukan 7 kasus dengan ARDS. Diantara penderita dengan TB, tipe milier atau disseminata sangat berisiko mengalami ARDS begitu pula penderita dengan adanya komorbid gangguan fungsi imun. ${ }^{5}$ Pada kasus ini akan dibahas seorang perempuan dengan tuberkulosis (TB) paru yang datang ke IRD Dr. Soetomo dengan ARDS.

\section{KASUS}

Seorang perempuan, 27 tahun, 12 hari pasca melahirkan, suku Jawa, datang ke RSUD Dr. Soetomo dengan keluhan utama sesak napas. Sesak napas sejak 1 minggu SMRS yang memberat 1 hari SMRS. Sesak napas terasa lebih berat saat aktivitas dan membaik dengan istirahat. Keluhan sesak napas telah dirasakan penderita sejak usia 9 bulan kehamilan tetapi tidak mengganggu aktivitas. Menurut penderita, ia telah menyampaikan keluhan ini kepada dokter akan tetapi dikatakan akibat kehamilan dan disarankan untuk memeriksakan diri ke dokter kandungan. Terdapat batuk tanpa dahak sejak 1 minggu SMRS. Tidak dikeluhkan adanya demam, hanya sumer-sumer. Penderita mengatakan terdapat penurunan napsu makan seiring kehamilannya yang semakin membesar. Adanya penurunan berat badan disangkal. Bengkak pada kaki disadari sejak 1 hari SMRS. Adanya riwayat bengkak pada kaki sebelumnya disangkal.

Berdasarkan data rujukan, penderita didiagnosa dengan edema paru ec kardiomiopati peripartum. Penderita tidak pernah mengalami sesak napas sebelumnya. Riwayat penyakit hipertensi, kencing manis, penyakit jantung, penyakit ginjal dan penggunaan obat rutin disangkal oleh penderita. Selain obat dari dokter kandungan berupa vitamin kehamilan, penderita tidak pernah mengomsumsi obat apa pun secara rutin. Penderita mempunyai riwayat partus pervaginan pada pemeriksaan di rumah sakit lain. Berdasarkan riwayat sosial, penderita tinggal di kamar kos sempit yang kurang memiliki ventilasi.

Berdasarkan pemeriksaan fisik yang dilakukan keadaan umum didapatkan kesan sakit berat, kesadaran kompos mentis, tekanan darah 110/70 $\mathrm{mmHg}$, nadi $106 \mathrm{x} / \mathrm{menit}$, frekuensi napas $32 \mathrm{x} / \mathrm{menit}$, dan suhu aksiler $37^{\circ} \mathrm{C}$. Pada pemeriksaan kepala dan leher penderita tampak anemis dan dispnea, tidak didapatkan tanda-tanda ikterus maupun sianosis, tidak tampak pembesaran kelenjar getah bening leher serta tidak didapatkan adanya peningkatan tekanan vena jugularis.

Pada inspeksi toraks didapatkan simetris baik pada konsisi statis dan dinamis, tidak tampak adanya abnormalitas bentuk dada dan vena kolateral. Pada palpasi didapatkan fremitus raba sedikit meningkat di kedua lapang paru. Pada perkusi didapatkan sonor di kedua lapangan paru. Pada auskultasi didapatkan bronkovesikuler di kedua lapangan paru disertai ronki di $2 / 3$ bawah lapang paru dan tidak terdengar adanya wheezing. Pada pemeriksaan jantung, abdomen, didapatkan dalam batas normal. Pemeriksaan anggota gerak didapatkan hangat, kering, merah. Didapatkan adanya edema pada kedua ekstrimitas bawah. Tidak didapatkan pembesaran kelenjar getah bening di ketiak maupun pelipatan paha.

Pemeriksaan darah lengkap dengan hasil leukosit 10,5 x 103/uL; limfosit 17,3\%; monosit 9,4\%; Granulosit 73,3\%; Hb 10,5 g/dL; MCV 82,3fL; MCH 26,7 pg; PLT 446 x103/uL; BUN 9,1mg/dL; Serum Creatinine 0,51 mg/dL; Glukosa 97 mg/dL; SGOT 33 U/L; SGPT 19 U/L; Albumin 2,95 mg/dL; Natrium $135 \mathrm{mmol} / \mathrm{L}$; Kalium 3,0 mmol/L; Klorida $91 \mathrm{mmol} / \mathrm{L}$. Analisis gas darah memberikan hasil pH 7,51; pCO2 43 mmHg; pO2 160 mmHg; HCO3 34,3 $\mathrm{mmol} / \mathrm{L}$; BE 11,3 mmol/L; SO2 100\%; AaDO2 65 mmHg dengan penggunaan masker oksigen nonrebreathing 8 liter per menit.

Pada pemeriksaan foto toraks (lihat gambar 1) ditemukan adanya gambaran retikulogranuler pattern pada kedua lapang paru yang dapat merupakan gambaran suatu interstitial pneumonia DD interstitial lung edema. Pada pemeriksaan EKG didapatkan jantung dengan sinus takikardia $110 \mathrm{x} /$ menit, terdapat nonspesifik ST-T changes. Sementara pada pemeriksaan ekokardiografi ditemukan hasil: katup-katup TR ringan, dimensi ruang jantung normal. Vegetasi (-). Thrombus (-), fungsi sistolik LV normal (EF by teach $75 \%$ biplane $74 \%$ ), fungsi diastolic LV normal, fungsi sistolik RV normal (TAPSE 2,1), analisa segmental LV normokinetik, tidak terdapat LVH, dan PCWP 12,25 mmHg; SVR 1371; PVR 313,943

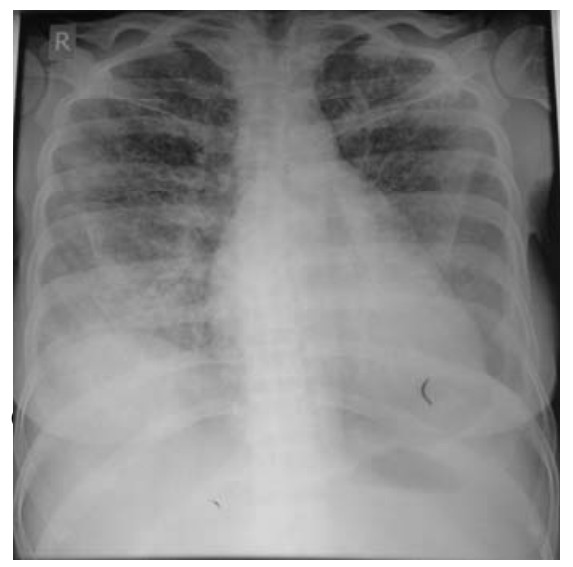

Gambar 1. Foto Toraks

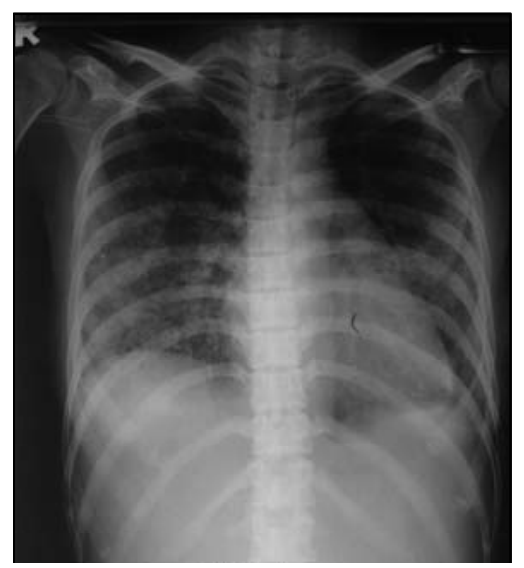


Pada tahap penegakan diagnosis juga dikonsultasi ke bagian anastesi dan reanimasi untuk pertimbangan perawatan intensif di ICU dengan hasil penderita dengan interstitial lung disease yang irreversible dan tidak ditemukan adanya indikasi perawatan di ICU.

Kultur darah menemukan adanya pertumbuhan kuman Staphylococcus haemolyticus yang sensitif terhadap cotrimoxazole, tetracycline, chloramphenicol, gatifloxacin, quinopristine-dalfopristine, moxifloxacin. Kultur urine tidak menemukan adanya pertumbuhan kuman. Pada hari kesepuluh, berdasarkan hasil VCT, HIV 3 metode dinyatakan negatif. Perawatan selanjutnya difokuskan untuk mengatasi infeksi dan memperbaiki kondisi umum penderita seperti hipoalbumin dan anemia.

Berdasarkan gambaran klinis dan perjalanan penyakit selama 14 hari dirawat penderita diberikan terapi dengan obat anti tuberkulosis (OAT) regimen rifampisin, isoniazid, etambutol, pyrazinamide dan streptomisim $(\mathrm{RHZE}+\mathrm{S})$. Pemeriksaan sputum basil tahan asam (BTA) memberikan hasil $+1 /-/-$. Kondisi penderita mengalami perbaikan 2 hari setelah terapi dan kemudian berangsur membaik 7 hari setelah pemberian OAT. Keluhan sesak napas berkurang, batuk masih dirasakan penderita dengan dahak yang lebih mudah dikeluarkan, tidak dirasakan adanya demam. Napsu makan membaik seiring dengan keluhan sesak yang berkurang. Dari heteroanamnesis terhadap rekan sekerja penderita didapatkan bahwa batuk muncul pertama kali 2 bulan sebelum penderita dirawat di rumah sakit, akan tetapi karena hilang-timbul dan tidak mengganggu aktivitas sehingga tidak dikeluhkan. Terdapat rekan sekerja penderita yang mengalami keluhan batuk serupa dan sedang dalam pengobatan dari puskesmas. Penderita kemudian dipulangkan setelah menjalani perawatan selama 28 hari.

Berdasarkan data selama perawatan di rumah sakit meliputi keluhan penderita, pemeriksaan fisik, laboratorium, radiologi dan pemeriksaan penunjang lainnya, akhirnya disimpulkan diagnosis TB paru kasus baru yang datang dengan manifestasi sesak napas ec ARDS (Acute Respiratory Distress Syndrome).

\section{DISKUSI}

Manifestasi klinis TB tergantung dari beberapa faktor yaitu usia, status imunitas, adanya penyakit penyerta, status imunisasi BCG, virulensi dari organisme yang menginfeksi dan interaksi antara host-agen. Adanya batuk kronis disertai penurunan berat badan dan penurunan napsu makan adalah gejala yang sering dikeluhkan oleh penderita dengan infeksi TB. ${ }^{6}$ Manifestasi sistemik lainnya berupa demam subfebris yang muncul pada $80 \%$ kasus, penurunan nafsu makan, penurunan berat badan, malaise, keringat malam merupakan gejala yang sering dikeluhkan. ${ }^{2}$

Batuk adalah gejala klinis tersering pada TB paru. Pada awal infeksi keluhan dapat berupa batuk yang tidak produktif akan tetapi dengan memberatnya proses inflamasi terjadi nekrosis jaringan serta adanya debris dari sel yang mati menginduksi mukosilier klirens maka batuk menjadi produktif. ${ }^{6}$ Sesak napas biasanya dikeluhkan pada penderita TB yang disertai infeksi penyerta seperti pneumonia akan tetapi dapat pula ditemukan pada kasus dengan infeksi tuberkulosis berat. Adanya perburukan kondisi dapat menimbulkan gagal napas yang berujung fatal. Adanya suara bronkial dan ronki pada asukultasi paru merupakan tanda konsolidasi pada area yang terkena infeksi. ${ }^{2,7}$

Pada penderita ini keluhan utama yang dirasakan penderita adalah sesak napas. Keluhan muncul pertama kali bersamaan dengan kehamilan pada trimester ketiga. Walaupun pada awalnya gejala dianggap bagian dari fisiologi kehamilan akan tetapi gejala sesak napas kemudian menetap bahkan mengalami perburukan setelah penderita melahirkan. Keluhan batuk pada awalnya dikatakan tanpa dahak dan baru muncul 1 minggu sebelum masuk rumah sakit akan tetapi setelah dilakukan anamnesa terhadap keluarga dan rekan sekerja penderita didapatkan data bahwa penderita telah terlihat mengalami batuk sejak bulan ke-8 kehamilan. Manifestasi sistemik infeksi TB pada awalnya tidak dikeluhkan. Penderitatidak mengeluhkan adanya penurunan berat badan akan tetapi setelah dilakukan anamnesa mendalam didapatkan bahwa berat badan penderita tidak bertambah saat kehamilan trimester akhir. Begitu pula adanya penurunan nafsu makan hanya dianggap sebagai akibat dari mual yang merupakan keluhan wajar pada kehamilan. Pada penderita ini terdapat pula adanya sumer, keringat malam, serta pembengkakan pada kaki.

\section{Gambaran radiologis dan laboratorium}

Pada foto polos, gambaran radiologi penderita dengan TB paru pada umumnya berupa infiltrat unilateral pada daerah apeks atau pada bagian superior lobus paru dengan atau tanpa kalsifikasi serta adanya kavitasi. ${ }^{5}$ Pada beberapa kasus dapat ditemukan adanya pembesaran limfonodi hilar. Akan tetapi pada kasus dengan penyakit penyerta atau infeksi yang berat gambaran umum ini dapat saja tidak muncul pada foto toraks penderita. Gambaran radiologis atipikal dapat ditemui pada penderita TB dengan koinfeksi HIV. Pada kondisi ini gambaran radiologis sangat bervariasi. $^{8}$

Area interstitium paru merupakan kumpulan jaringan penyokong yang terdiri dari pembuluh darah, bronkus dan jaringan ikat. Pada foto toraks normal, area interstitium yang terlihat berada di hilus di mana terdapat kumpulan dari pembuluh darah. Semakin perifer area ini semakin tidak terlihat. Pada kondisi adanya kelainan pada paru terutama apabila mengakibatkan penebalan dari jaringan interstitium maka akan terjadi peningkatan radiodensitas yang akan terlihat pada foto toraks. Apa bila kelainan ini bersifat menyeluruh (generalisata atau difusa) maka interstitium akan tampak pola linear atau retikular sementara apabila terlokalisir maka akan terlihat sebagai nodul kecil multipel. ${ }^{9}$ Terdapat 4 pola gambaran opasitas pada interstitial yaitu

linear, retikular, nodular dan retikulonodular (lihat gambar 2). ${ }^{6,10}$ 


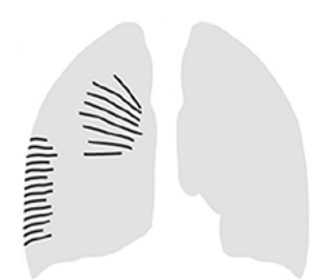

Linear

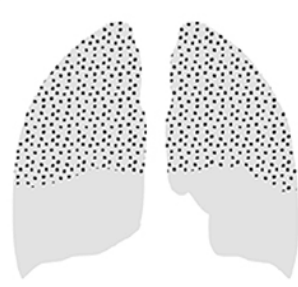

Nodular

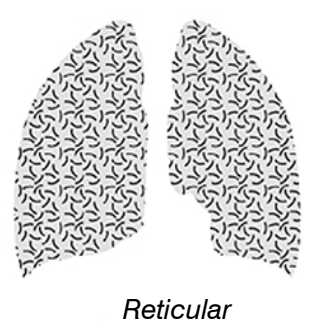

Reticular

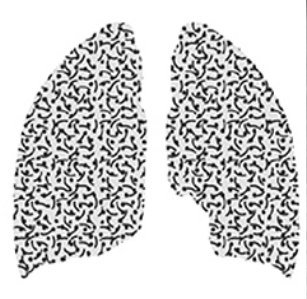

Reticulonodular

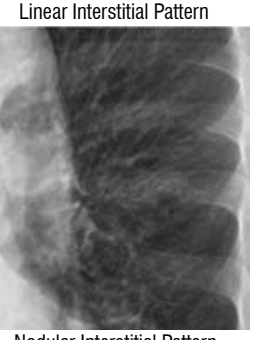

Nodular Interstitial Pattern
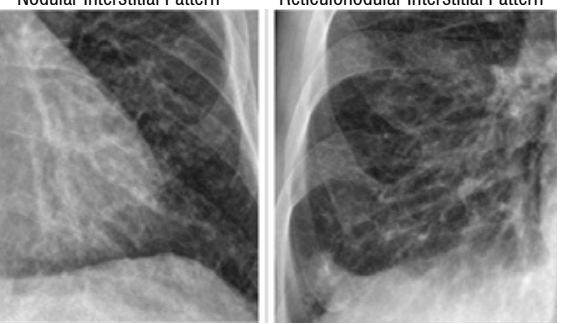

Gambar 2. Skema pola opasitas interstitial pada paru beserta gambaran radiologisnya. ${ }^{9}$

Pada penderita ini didapatkan gambaran retikulonodular pada kedua lapang paru. Berdasarkan gambaran foto toraks diduga terdapat edema paru atau merupakan suatu gambaran pneumonia interstitial. Pada proses penegakan diagnosis tidak ditemukan adanya tanda-tanda gagal jantung berdasarkan hasil ekokardiografi. Penderita kemudian dicurigai mengalami edema paru non kardiogenik atau ARDS (Acute Respiratory Distress Syndrome) yang mungkin diakibatkan dari pneumonia insterstitial. Akan tetapi kondisi penderita mengalami perburukan sehingga berdasarkan gambaran klinis dan perjalanan penyakit maka diberikan OAT.

Hal yang serupa dilaporkan oleh Hameed, et al mengenai perempuan 32 tahun tanpa komorbiditas yang datang dengan keluhan sesak napas selama 4 minggu. Pada pemeriksaan fisik penderita sadar baik dengan rerata respirasi $34 \mathrm{x} /$ mnt dan saturasi oksigen hanya $70 \%$. Pemeriksaan fisik paru mendapatkan adanya ronki pada kedua lapang paru sementara hasil laboratorium dalam batas normal. Analisa gas darah memperlihatkan kondisi gagal napas dengan rasio Po2/FiO2 sebesar 198. Foto toraks memperlihatkan adanya pola retikulonodular bilateral dengan infiltrat halus. Penderita kemudian diintubasi dan diberikan antibiotika spektrum luas akan tetapi tidak terdapat perbaikan kondisi. Berdasarkan kecurigaan klinis dan radiologis maka dimulai pemberian obat anti tuberkulosis (OAT). Kondisi penderita kemudian berangsur mengalami perbaikan dalam 7 hari setelah terapi dimulai. ${ }^{12}$

\section{Infeksi Tuberkulosis pada Kehamilan}

Beberapa faktor yang mempengaruhi terjadinya infeksi TB adalah adanya sumber infeksi, virulensi dari kuman M.tb, menurunnya daya tahan tubuh sehingga memungkinkan kuman berkembang biak. Penurunan daya tahan tubuh seseorang ditentukan oleh faktor genetik, umur, lingkungan, bahan toksik, imunologis, kondisi komorbiddan psikologis. ${ }^{2}$ Pada penderita ini kerentanan pada host mungkin diakibatkan oleh karena perubahan fisiologis selama kehamilan sementara strain M.tb yang menyebabkan infeksi belum diketahui jenisnya sehingga daya virulensinya belum diketahui.

Seiring dengan bertambahnya usia kehamilan maka akan terjadi perubahan anatomi rongga dada. Terjadi pergeseran diafragma ke atas akibatnya diameter anteroposterior dan transversal yang meningkat sehingga volume residu dan volume cadangan ekspirasi menurun $10-40 \%$ sementara volume tidal dan ventilasi semenit akan meningkat $20-40 \% .{ }^{13} \mathrm{Hal}$ ini diakibatkan oleh karena bertambahnya ukuran uterus serta pengaruh dari progesteron dan $\beta$-HCG. Kebutuhan oksigen meningkat $20-33 \%$ pada kehamilan trimester pertama akibat peningkatan proses metabolik pada ibu dan kebutuhan oksigen pada janin. Adanya perubahan hormon estrogen pada kehamilan mengakibatkan edema, hiperemi dan hipersekresi dari mukosa saluran napas yang nantinya mengakibatkan penurunan kemampuan klirens mukosiler. ${ }^{14}$

Infeksi TB pada kehamilan tidak hanya berdampak pada ibu tapi juga janin. Hal ini tergantung dari luasnya lesi, umur kehamilan, status gizi, status imunologi, adanya penyakit penyerta serta ketersediaan sarana diagnostik dan terapi. ${ }^{15}$ Jika terjadi keterlambatan diagnosis dan terapi maka risiko persalinan prematur akan meningkat sebanyak 9 kali dibanding wanita hamil tanpa infeksi TB. Selain itu terdapat pula risiko abortus spontan, berat badan lahir rendah dan kematian janin dalam rahim. Janin dapat tertular TB melalui vena umbilikal, ASI atau air ketuban yang terinfeksi selama proses persalinan. ${ }^{16}$ Anak dengan infeksi TB kongenital akan terlihat lemah, tidak mau menyusu, demam, terdapat limfadenopati, hepatosplenomegali, dan distres napas..$^{15,16}$ Pada penderita ini didapatkan riwayat persalinan spontan normal, cukup bulan, berat badan lahir bayi normal. Akan tetapi dikatakan bayi meninggal pada usia 20 hari akibat demam dan sulit bernapas. Tidak diketahui dengan 
pasti penyebab kematian karena tidak sempat diberikan pertolongan oleh tenaga kesehatan. Riwayat persalinan sebelumnya normal dengan berat badan lahir cukup dan saat ini anak pertama penderita telah berusia 4 tahun.

\section{ARDS (Acute Respiratory Distress Syndrome)}

Istilah ARDS (Acute Respiratory Distress Syndrome) pertama kali diperkenalkan oleh Ashbaugh dan kolega untuk menggambarkan 12 penderita dengan gagal napas akut yang kemudian mengalami perburukan. ARDS adalah kondisi mengancam jiwa yang diakibatkan oleh karena infeksi atau trauma pada paru. Adanya inflamasi pada parenkim paru akan mengakibatkan gangguan pertukaran gas, hipoksemia dan kegagalan fungsi organ. ${ }^{3}$ Angka mortalitas pada penyakit ini mencapai $90 \%$ akan tetapi dengan diagnosis dini dan terapi yang adekuat maka angka mortalitas dapat ditekan hingga menjadi 50\%.${ }^{17}$

Menurut kriteria Berlin, diagnosis ARDS dapat ditegakkan jika terdapat onset akut dari gejala respirasi atau perburukan gejala respirasi pada kasus infeksi atau trauma paru dengan gambaran radiologis berupa opasitas bilateral yang sesuai dengan gambaran edema paru, akan tetapi tidak disebabkan oleh kegagalan jantung atau adanya kelebihan (overload) cairan. Menurut kriteria America-Europa Consensus Conference Committee hal ini dibuktikan dengan PAWP (pulmonary artery wedge pressure) $<18$. Berdasarkan rasio $\mathrm{PaO} 2: \mathrm{FiO} 2$ maka ARDS dapat dibedakan menjadi ringan (rasio $\mathrm{PaO} 2$ :FiO2 200-300), ARDS sedang (rasio PaO2:FiO2 100-200), dan berat (rasio PaO2:FiO2 $<100$ ). Kriteria ini cukup mudah diaplikasikan di lapangan walaupun tetap memiliki keterbatasan terutama pada gambaran radiologis. ${ }^{18,19}$

Pada penderita ini onset perburukan gejala respirasi terjadi 1 minggu sebelum masuk rumah sakit dengan riwayat adanya infeksi sebelumnya diperlihatkan dengan gejala sesak batuk dan demam yang telah muncul 2 bulan sebelumnya. Gambaran foto toraks berupa opasitas retikulonodular bilateral dengan analisa gas darah saat penderita datang ke IRD RS Dr Soetomo memperlihatkan penderita mengalami ARDS derajat sedang dengan rasio $\mathrm{PaO} 2 / \mathrm{FiO} 2$ sebesar 107. Analisa gas darah serial kemudian memperlihatkan adanya perbaikan pertama kali pada hari 7 perawatan dengan rasio $\mathrm{PaO} 2 / \mathrm{FiO} 2$ 207,5. Dengan perbaikan kondisi penderita maka rasio ini kemudian berangsur mengalami peningkatan.
Patogenesis terjadinya ARDS pada infeksi TB belum sepenuhnya dapat dijelaskan. Membran alveolar-kapiler terdiri dari jaringan mikrovaskuler, interstitium dan epitel alveoli. Inflamasi akut mengakibatkan rusaknya endothelium dan barrier epitel. ${ }^{4}$ Adanya infeksi atau trauma akan meningkatkan pelepasan sitokin proinflamasi sebagai respons jejas seluler. Pada kondisi normal sel epitel tipe I dan II bertindak secara selektif sebagai sawar. Peningkatan permeabilitas dari membran selama fase akut jejas paru memungkinkan masuknya cairan tinggi protein ke dalam interstitium peribronkial kemudian ke ruang alveoli. Jejas pada sel tipe I dan II mengakibatkan gangguan pada transportasi cairan melalui penurunan jumlah pompa Na-K yang mengganggu proses perbaikan dari edema paru. Jejas pada sel epithelial tipe 2 juga menurunkan produksi surfaktan sehingga secara umum menurunkan kemampuan paru untuk mengembang (komplian). ${ }^{17,19}$

Migrasi dan aktivasi neutrophil mengakibatkan kerusakan pada membran basalis dan kemudian meningkatkan permeabilitas dari barrier alveolar-kapiler. Banyaknya migrasi neutrophil secara mekanis akan memperbesar gap antar sel selain itu neutrophil akan melepaskan mediator pro inflamasi dan pro apoptosis yang bekerja pada sel setempat sehingga menimbulkan lesi ulseratif. ${ }^{19}$ Beberapa studi melaporkan adanya sitokin inflamasi yang dapat dipergunakan sebagai penanda adanya ARDS maupun penanda risiko mortalitas. Kadar IL-6, IL-8, TNF- $\alpha$, ICAM-1, serta VCAM-1 merupakan beberapa contoh prediktor mortalitas yang sedang diteliti. ${ }^{17}$

\section{Infeksi Tuberkulosis dengan ARDS}

Penelitian terbaru menunjukkan adanya hubungan antara ARDS (Acute Respiratory Distress Syndrome) dengan TB paru. Identifikasi penyebab distres napas sangat penting dalam inisiasi terapi dini. TB Paru dengan komplikasi ARDS memiliki angka mortalitas yang lebih tinggi sebesar 33-90\%. ${ }^{5}$ Walaupun telah banyak dibahas, TB paru dengan komplikasi ARDS tetap sulit ditegakkan di praktik klinik sehari-hari. Hal ini disebabkan oleh karena manifestasi klinis yang dapat ditimbulkan oleh penyakit ini sangat bervariasi. Hameed, et al melaporkan dari 109 penderita dengan TB paru milier terdapat 7 penderita dengan ARDS. ${ }^{12}$ Tuberkulosis milier adalah diseminasi luas dari M.tb salah satunya melalui jalur hematogenous.

Tabel 1. Kriteria Berlin untuk ARDS (Acute Respiratory Distress Syndrome) ${ }^{18}$

\begin{tabular}{ll}
\hline & \multicolumn{1}{c}{ ARDS (Acute Respiratory Distress Syndrome)- Berlin Criteria } \\
\hline Waktu & Dalam waktu 1 minggu setelah adanya jejas atau gejala respirasi baru atau perburukan gejala respirasi \\
Radiologi Paru & Opasitas Bilateral- yang tidak dapat dijelaskan oleh efusi, kolaps paru atau nodul \\
Sumber Edema & $\begin{array}{l}\text { Adanya gagal napas yang tidak dapat dijelaskan oleh gagal jantung atau } \text { overload cairan } \\
\text { Diperlukan pemeriksaan obyektif (seperti ekokardiografi) untuk mengekslusi adanya edema hidrostatik } \\
\text { jika tidak ada faktor risiko yang ditemukan }\end{array}$ \\
& \\
Oksigenasi & $200<\mathrm{PaO}_{2} / \mathrm{FiO}_{2} \leq 300$ with PEEP or CPAP $\geq 5 \mathrm{cmH}_{2} \mathrm{O}^{\mathrm{c}}$ \\
Ringan & $100<\mathrm{PaO}_{2} / \mathrm{FiO}_{2} \leq 200$ with PEEP or CPAP $\geq 5 \mathrm{cmH}_{2} \mathrm{O}$ \\
Sedang & $\mathrm{PaO}_{2} / \mathrm{FiO}_{2}<100$ with PEEP or CPAP $\geq 5 \mathrm{cmH} \mathrm{Cm}_{2} \mathrm{O}$ \\
Berat &
\end{tabular}




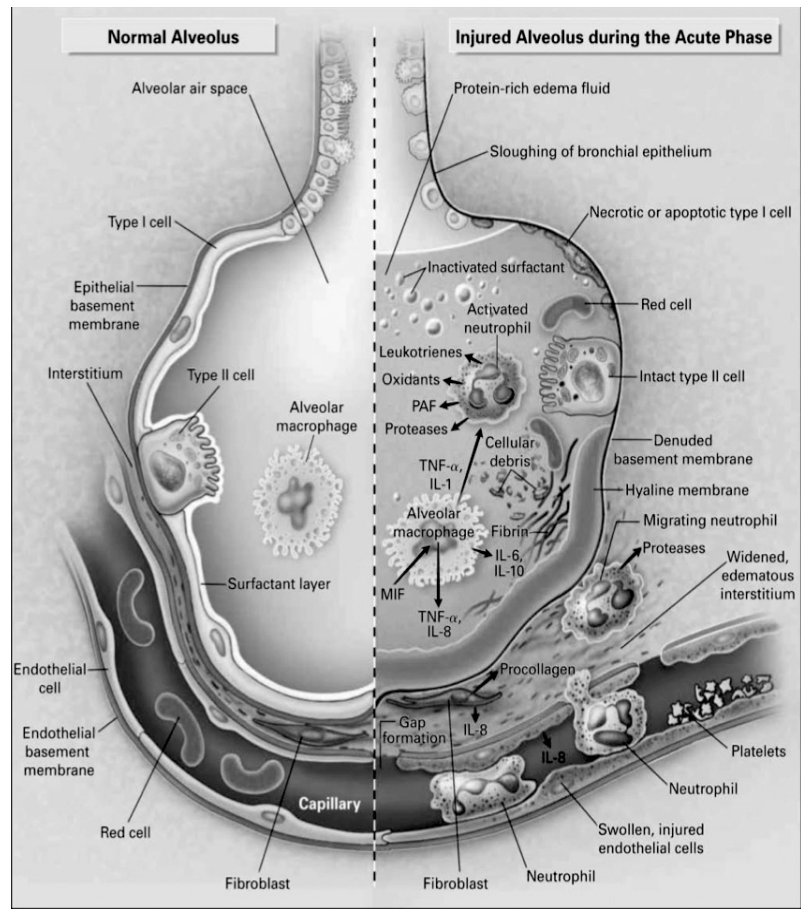

Gambar 3. Alveoli: perubahan yang terjadi pada alveoli selama fase akut jejas pada paru. ${ }^{17}$

Terdapat banyak faktor yang menjadi predisposisi munculnya TB milier termasuk ko-infeksi HIV, diabetes mellitus, dan penggunaan agen immunosuppressif, steroid dan alkohol. Manifestasi klinis dapat berupa demam, disfungsi organ, syok sepsis dan ARDS yang muncul terutama pada penderita dengan gangguan sistem imun. Karena gambarannya yang tidak spesifik maka diagnosis pada kasus ini seringkali terlewatkan dan hanya terdeteksi postmortem. ${ }^{20}$

Pada kasus ini dilaporkan penderita yang datang dengan batuk dan penurunan berat badan serta ronki bilateral pada basal paru. Laboratorium memperlihatkan peningkatan enzim hati sementara TST (tuberculin skin test), smear sputum gram serta BTA memberikan hasil negatif. Pada hari kelima perawatan penderita mengalami perburukan dan distres napas, foto toraks memperlihatkan adanya infiltrat difus bilateral. Penderita kemudian diintubasi dan diberikan ventilasi mekanik. Berdasarkan kecurigaan terhadap ARDS terkait TB milier maka pada penderita ini dimulai terapi empiris dengan anti tuberkulosis dan steroid. Penderita diekstubasi setelah 6 hari dan dipulangkan dengan gambaran radiologis hampir normal. ${ }^{5}$

Hal yang sama dilaporkan oleh penderita dalam kasus ini di mana penderita datang dengan gejala sesak napas yang kurang spesifik untuk infeksi TB. Pada penderita kemudian terjadi perburukan kondisi disertai distres napas bahkan setelah pemberian antibiotika. Adanya koinfeksi HIV telah disingkirkan dengan hasil negatif dari pemeriksaan VCT. Berdasar kecurigaan terhadap ARDS yang menyertai infeksi TB maka pada penderita ini dimulai terapi empiris anti tuberkulosis. Kondisi penderita mengalami perbaikan 7 hari setelah terapi OAT.
Pada suatu studi oleh Deng, et al. dikemukakan adanya faktor prediktor independen risiko ARDS pada TB paru seperti kadar serum SGOT, SGPT, albumin dan adanya diabetes mellitus. Dilaporkan bahwa terdapat perbedaan signifikan kadar AST, ALT dan albumin serum pada penderita pasca ARDS dengan penderita yang meninggal. ${ }^{20}$ Albumin memainkan peranan penting dalam regulasi osmolalitas plasma. Hipoproteinemia dengan cepat dapat menimbulkan eksudasi cairan, edema alveolar, dan ketidakseimbangan ventilasi-perfusi. Jika proses ARDS berlanjut terjadi disfungsi organ yang mengakibatkan peningkatan serum transaminase. ${ }^{19,20}$ Pada penderita ini tidak ditemukan adanya komorbiditas seperti ko-infeksi HIV, diabetes mellitus, penggunaan steroid jangka panjang maupun konsumsi alkohol. Dari evaluasi hasil laboratorium ditemukan kadar albumin yang rendah sepanjang masa perawatan sementara kadar SGOT maupun SGPT serum masih dalam batas normal.

Pada kasus ini awalnya dicurigai suatu gagal jantung diastolik yang mengakibatkan edema paru. Disfungsi diastolik adalah abnormalitas yang terjadi pada saat pengisian selama fase diastolik. Pada fase ini terjadi pengisian ventrikel dan atrium secara pasif akibat perbedaan gradient tekanan. Pada jantung yang normal darah mengalir tanpa hambatan dari paru menuju vena pulmonalis, masuk ke dalam atrium kiri kemudian ventrikel kiri. Apabila terjadi hambatan dan darah tidak dapat masuk ke ventrikel kiri secara optimal maka terjadi tekanan balik ke atrium kiri kemudian ke paru. Apabila hal ini berlanjut, perbedaan tekanan akan mengakibatkan bendungan pada paru yang mengakibatkan edema paru. ${ }^{21}$

Keterlibatan jantung pada kasus infeksi TB terjadi pada 1-2\% kasus dengan predileksi perikardium. Akan tetapi tidak dapat disingkirkan adanya keterlibatan miokardium walaupun jarang dilaporkan. Pada suatu laporan kasus oleh Agarwal, et al. di India ditemukan penderita perempuan 25 tahun dengan gagal jantung yang diakibatkan oleh infeksi TB. Penyebaran ke miokardium dapat melalui jalur hematogen atau sistem limfatik atau secara penyebaran langsung dari perikarditis tuberkulosa. ${ }^{22}$ Pada beberapa literatur dikatakan TB miokardium memiliki beragam manifestasi kardiak dan dapat mengakibatkan gangguan irama jantung termasuk supraventrikular takikardia, blok jantung, obstruksi pada ventrikel kanan, aneurisma ventrikel, arteritis coroner dan gagal jantung kongestif. Infeksi TByang mengakibatkan gagal jantung melalui arteritis dilaporkan pula oleh Aurora et al. pada penderita perempuan, 30 tahun di Kosova, Rusia. ${ }^{23}$ Data di Amerika sendiri berdasarkan FDA (Food and Drug Association) dilaporkan terdapat 3 kasus kardiomiopati pada 1987 orang dengan TB dan ketiganya merupakan perempuan yang berusia antara 20-29 tahun serta memiliki ko-infeksi HIV. ${ }^{21}$

\section{Manajemen terapi ARDS}

Prinsip penanganan ARDS adalah menjaga oksigenasi dan terapi suportif sementara mengidentifikasi dan 
menangani penyebab dasarnya. Sangat penting untuk ditekankan bahwa apabila respons terapi tidak sesuai dengan yang diharapkan maka perlu dipikirkan adanya kemungkinan terapi yang tidak adekuat atau misdiagnosa. ${ }^{22}$ Terapi suportif termasuk kontrol kadar gula, pencegahan DVT (trombosis vena dalam), stress ulcer dan VAP (ventilator-associated pneumonia) serta infeksi akibat kateterisasi. Pemberian nutrisi enteral secara dini juga dikatakan mampu membantu perbaikan kondisi penderita. Walaupun masih menjadi kontroversi mengenai jumlah, jenis dan waktu yang tepat untuk enteral nutrisi tersebut. ${ }^{4}$

Ventilasi mekanik berfungsi untuk menjaga pertukaran gas hingga kerusakan seluler dapat teratasi. Pemberian PEEP (Positif End Expiration Pressure) dapat meningkatkan oksigenasi pada kasus ARDS dengan menjaga patensi dari alveoli yang rusak sehingga meningkatkan V/Q dan mengurangi shunt intrapulmoner. ${ }^{5}$ Pada suatu studi yang dilakukan oleh ARDSnet didemonstrasikan bahwa tidak terdapat perbedaan outcome maupun mortalitas antara penderita dengan ventilasi PEEP rendah $(8 \mathrm{~cm}$ h20) maupun dengan ventilasi tinggi (14 cm h20). Uji klinis yang dilakukan pada 861 penderita dengan ARDS memperlihatkan angka mortalitas yang lebih rendah diasosiasikan dengan kelompok dengan tidal volume yang lebih rendah. Strategi ini bahkan dapat mengurangi s inflamasi oleh IL-6 dan IL-8. ${ }^{17}$

Sebagai akibat dari perubahan permeabilitas kapiler, penumpukan cairan akan mengganggu pertukaran gas. Cairan berlebih akan meningkatkan tekanan hidrostatis kapiler yang nantinya akan mengakibatkan edema paru. ${ }^{20}$ Karena itu beberapa studi menekankan manfaat dari restriksi cairan, akan tetapi pemberian cairan akan memperbaiki cardiac output sehingga perfusi ke perifer lebih baik, Pada suatu studi oleh FACTT ditemukan penderita dengan restriksi cairan memiliki durasi pemakaian ventilasi dan perawatan ICU yang lebih pendek dibandingkan penderita tanpa restriksi cairan akan tetapi tidak ditemukan perbedaan angka mortalitas antara keduanya. ${ }^{17}$

Steroid memilliki efek anti inflamasi dengan menghambat metabolism asam arakidonat dan mengurangi aktivitas eosinophil. Akan tetapi studi meta analisis terhadap penggunaan metil prednisolon tidak memberikan hasil signifikan terhadap reduksi angka mortalitas. Karena itu rekomendasi penggunaan rutin steroid sebagai standar terapi masih menjadi kontroversi. ${ }^{12}$ Penelitian terakhir menemukan adanya manfaat dari penggunaan surfaktan eksogen, inhalasi NO, prostaglandin E1, glukokortikoid, $\mathrm{N}$-acetylcysteine, dan protein $\mathrm{C}$ sebagai penanganan ARDS akan tetapi studi fase 3 tidak memberikan hasil yang menggembirakan. Data preklinis juga menunjukkan adanya potensi -2 agonis sebagai salah satu terapi. Agen ini dapat meningkatkan resolusi edema paru dengan cara menurunkan inflamasi dan meningkatkan transport garam dan air. Salbutamol intravena telah dibuktikan secara signifikan mengurangi cairan paru ekstravaskuler. Akan tetapi uji klinis terhadap albuterol belakangan telah dihentikan karena analisa futilitas menunjukkan lebih banyak efek buruk dibanding manfaat. ${ }^{4}$ Selain penanganan ARDS secara tepat diperlukan pula diagnosis yang akurat sehingga penyebab dasarnya dapat teratasi.

Pada kasus ini penderita ventilasi mekanik tidak dapat diberikan akibat keterbatasan sumber daya akan tetapi terapi suportif yang optimal dapat membantu meningkatkan kondisi umum penderita. Pada penderita ini diaplikasikan restriksi cairan dimana cairan infus berupa normal salin diberikan $500 \mathrm{cc}$ per hari dengan pembatasan jumlah cairan yang dikonsumsi. Pada penderita ini juga diberikan terapi steroid menggunakan metil prednisolon untuk mengurangi beban inflamasi. Akan tetapi pemberian terapi anti tuberkulosis secara signifikan dapat memperbaiki kondisi penderita. Pada kenyataannya akibat gejala klinis yang tidak spesifik seringkali diagnosis menjadi tertunda sehingga terapi pun juga tertunda.

\section{KESIMPULAN}

Tuberkulosis adalah penyakit dengan insidens dan prevalensi tinggi di seluruh dunia termasuk di Indonesia. Diagnosa banding untuk penyakit ini sangat beragam dari keganasan hingga berbagai macam infeksi. Akan tetapi kasus dengan TB sebagai penyebab utama ARDS (Acute Respiratory Distress Syndrome) jarang dilaporkan. Pada makalah ini dilaporkan seorang perempuan muda dengan infeksi TB dengan penyulit ARDS. Penegakan diagnosa ARDS sesuai dengan kriteria Berlin sementara diagnosaTB ditegakkan melalui gejala klinis, gambaran radiologis dan laboratorium terutama melalui penemuan basil tahan asam pada sputum penderita. Akan tetapi pada kasus ini terjadi keterlambatan diagnosisTB akibat gejala yang tidak khas sehingga terapi pada awalnya dimulai berdasarkan kecurigaan klinis dan laboratoris. Pemeriksaan mikrobiologis kemudian memberikan hasil positif 1 hari setelah terapi dimulai. Pada penderitaini diberikan terapi suportif untuk ARDS, ventilasi mekanik tidak dapat diberikan akibat keterbatasan sumber daya. Terapi antituberkulosis memberikan respons perbaikan kondisi setelah 7 hari pemberian.

\section{DAFTAR PUSTAKA}

1. Global tuberculosis report 2012. [cited Mei 2014]. Available at: www. WHO-TB.org

2. Serafino R. Clinical manifestations of pulmonary and extra-pulmonary tuberculosis. South Sudan Medical Journal. 2013; 6(3): 52-56.

3. Mackay A, Haddad M.Acute lung injury and acute respiratory distres syndrome. Cont Edu Anaesth Crit Care and Pain. 2009; 9(5): $152-156$.

4. Lee K, Kim J, Park M, et al. Acute respiratory distress syndrome caused by miliary tuberculosis: a multicentre survey in South Korea. INT J TUBERC LUNG DIS. 2011; 15(8): 1099-1103.

5. Hadeel A, Abdul-Ghafoor A. Acute respiratory distress syndrome with miliary tuberculosis. Saudi Med J. 2012; 33 (1): 83-86.

6. Otto B, Zürcher H, Schweiz W. The Clinical Presentation of Tuberculosis. Respiration. 1998; 65: 97-105. 
7. Rajesh S, RichaRan K, JayapRaKash K, et al. Cardiac Involvement in Patients with Pulmonary Tuberculosis. Journal of Clinical and Diagnostic Research. 2011; 5 (3): 440-442.

8. Surendra S, Mohan A. Miliary tuberculosis in In David S (ed). Tuberculosis and nontuberculosis mycobacterial infection.6 ed.ASM Press, Washington DC. 2011: 415-435.

9. Scott D, Adam U, Todd R, et al. Revisiting the pattern approach to interstitial lung disease on chest radiography. Applied radiology.2009; 12(38): 278-283.

10. Norman A. Radiographic Diagnosis of Pulmonary Disease. 2001 [cited Mei 2014] Available at: http://www.vetlatranquera.com.ar

11. Wayne W,Nestor M, David P. High-resolution CT of the Lung. $3^{\text {rd }}$ ed. Lippincott Williams \& Wilkins. Philadelphia. 2008: 428-439.

12. Hameed R, Bhat A, Fayaz B, et al. Pulmonary tuberculosis presenting with acute respiratory distress syndrome (ARDS): A case report and review of literature. Egyptian Journal of Chest Diseases and Tuberculosis. 2013; 4(62): 655-659.

13. Rudra A, Ray A, Chatterjee S, et al. Trauma in Pregnancy. Indian Journal of Anesthesiology. 2007; 51(2): 100-105.

14. Bhatia P. Pregnancy and the lungs. Postgrad Med J. 2000; 76: 683-689.

15. David F, Stephen C. Pregnancy: maternal,fetal and neonatal consideration. In David S (ed).Tuberculosis and nontuberculosis mycobacterial infection.6 ed. ASM Press, Washington DC. 2011: 476-479.
16. Sharma S. Pulmonary Disorder in Pregnancy. US Respiratory disease 2011; 7: 36-42.

17. Johnson B, Mattay A, Elizabeth R. Acute Lung Injury: Epidemiology, Pathogenesis, and Treatment. Journal Of Aerosol Medicine And Pulmonary Drug Delivery. 2010; 4(23): 243-252.

18. Ioannis $\mathrm{P}$, Vasilios E. The new Berlin definition: what is, finally, the ARDS? PNEUMON. 2012; 4 (25): 365-368.

19. Marco R, Gordon R, Thompson T, et al. Acute respiratory distress syndrome: The Berlin definition. JAMA. 2012; 307 (23): 25262533.

20. Deng et al. Predictors and outcome of patients with acute respiratory distress syndrome caused by miliary tuberculosis: a retrospective study in Chongqing, China. BMC Infectious Diseases. 2012; 12 (121): 1471-2334.

21. Sunan G, Bharati I.Tuberculous coronary arteritis with aneurysm of the ventricular septum.CHEST. 1971; 6 (60): 613-616.

22. Agarwal R, Puneet M, Anshu A, et al. Tuberculous dilated cardiomyopathy: an under-recognized entity? BMC Infectious Diseases. 2005; 5 (29): 1471-1475.

23. Aurora B, Behxhet O, Lulzim K, et al. Acute myocardial infarction and pulmonary tuberculosis in a young female patient: a case report Cases Journal. 2008; 1: 246-250. 